\title{
The Conservation Measures of NATURA 2000 "Someşul Rece" Site Management Plan
}

\author{
Marian PROOROCU, Mădălina MICLĂUŞ, Sînziana PAULIUC*, Sonia BODAN, Andreea POPA \\ ${ }^{1}$ Department of Plant and Environmental protection. University of Agriculture Sciences and Veterinary \\ Medicine, ClujNapoca, Roumania \\ ${ }^{*}$ Corresponding author, e-mail: sinzianapauliuc@yahoo.com
}

Bulletin UASVM series Agriculture 73(2)/2016

Print ISSN 1843-5246; Electronic ISSN 1843-5386

DOI 10.15835/buasvmcn-agr: 12438

\begin{abstract}
Natura 2000 is a European network of protected natural areas including a significant number of natural habitats and wild species for the interest of comunnity. Natura 2000 ROSCI 0233 "Someşul Rece" Site is situated in the south-western county of Cluj, on the administrative territory of Măguri-Răcătău and Ierii Valley. It has an area of 8529 ha and is a framed area of the Apuseni Mountains Alpine bioregions. The site preserves the following natural habitats: Rough mountain beech forests Asperulo-Fagetum, beech forests of Luzulo-Fagetum, forests acidophilous Picea Abies mountain region and protect important species and active fish fauna, flora and fauna of the Apuseni Mountains. It is also home for several species (mammals, amphibians, fish and beetles) like: lynx, wolf or otter. The conservation measures of Natura 2000 Somesul Rece Site, elaborated in order to protect the habitats and the species are part of the management plan. These measures were developed in close connection with the conservation status of habitats and species, but also taking into account the needs of local communities. These measures include: maintaining habitats in favorable conservation status; maintain the current habitat areas; preventing and combating poaching and overfishing;ensuring peace in areas of rock (for large mammals).
\end{abstract}

Keywords: Site Natura2000, developing management plan, habitat, favorable condition.

\section{INTRODUCTION}

Natura 2000 is a European network of protected natural areas including a significant number of natural habitats and wild species for the interest of community (The Council Directive 92/43/EEC). Natura 2000 site ROSCI 0233 "Someşul Rece" is situated in the south-western county of Cluj, on the administrative territory of Măguri-Răcătău in Ierii Valley. It covers an area of 8529 ha and is a framed area of the Apuseni Mountains Alpine bioregions. The site preserves the following natural habitats: Rough mountain beech forests Asperulo-Fagetum, beech forests of Luzulo-Fagetum, forests acidophilous Picea Abies mountain region and protect important species and active fish fauna, flora and fauna of the Apuseni Mountains (Management plan of Natura 2000 Someșul Rece Site).

The site was declared for the following priority habitats: 6520 Rough Mountain -; 6150
Pajiti boreal and alpine silicon substrate; 9110 beech forests of Luzulo-Fagetum; 9130 beech forests Fagetum Asperulo; 91E0* Alluvial forests with Alnus glutinosa and Fraxinus excelsior (AlnoPadion, Alnion incanae, Salicion albae) - priority habitat; 9410 Forest acidofile Picea Abies in the mountain region (Vaccinio-Piceetea); $7110^{*}$ active peatlands - priority habitat; 91D0* peatland forest vegetation - priority habitat.

Regarding fauna, on the territory of the site we encounter the next protected species:

- Mammals: Canis lupus (wolf), Lynx lynx (lynx)

- Amphibians: Bombina variegata (yellowbellied toad)

- Fishes: Gobioura uranoscopus (Danubian longbarbel gudgeon), Sabanejewia aurata, Cottus gobio (European bullhead), Eudontomyzon danfordi ( Carpathian brook lamprey) 


\section{MATERIALS AND METHODS}

The conservation measures were established using field studies and bibliographic data. According to the field studies, conservation status for each type of habitat and species was set. Knowing the conservation status (favorable, unfavorable, inadequate, bad), we could elaborate proper conservation measures for all the community interest habitats and species within the site.

Evaluating the conservation status is crucial in the process of developing a management plan for a protected area. The specific objectives, measures, activities and rules required for each type of habitat, species or group of species of the areas result from their present state of preservation (Proorocu, 2008, Proorocu and Beldean, 2007).. Thus, if the conservation status is evaluated as favorable when we elaborate a management plan, the activities must maintain the conservation status for long-term. The rules and the results of the human impact must prevent and combat those activities whose potentially impact could influent the favorable conservation status in the future (Proorocu, 2008).

If the conservation status of a species/a habitat is evaluated as "unfavorableinadequate" or "unfavorable-bad", the activities of the management plan should focus in order to improve those parameters that prevent these pecies and/or habitat to reach a favorable conservation status. Also, the rules and the results of the human impact must reduce or eliminate the present activities with impact on the species/habitat type; it is also necessary to evoid any future activities that could affect species or habitats that have an unfavorable conservation status (Proorocu,

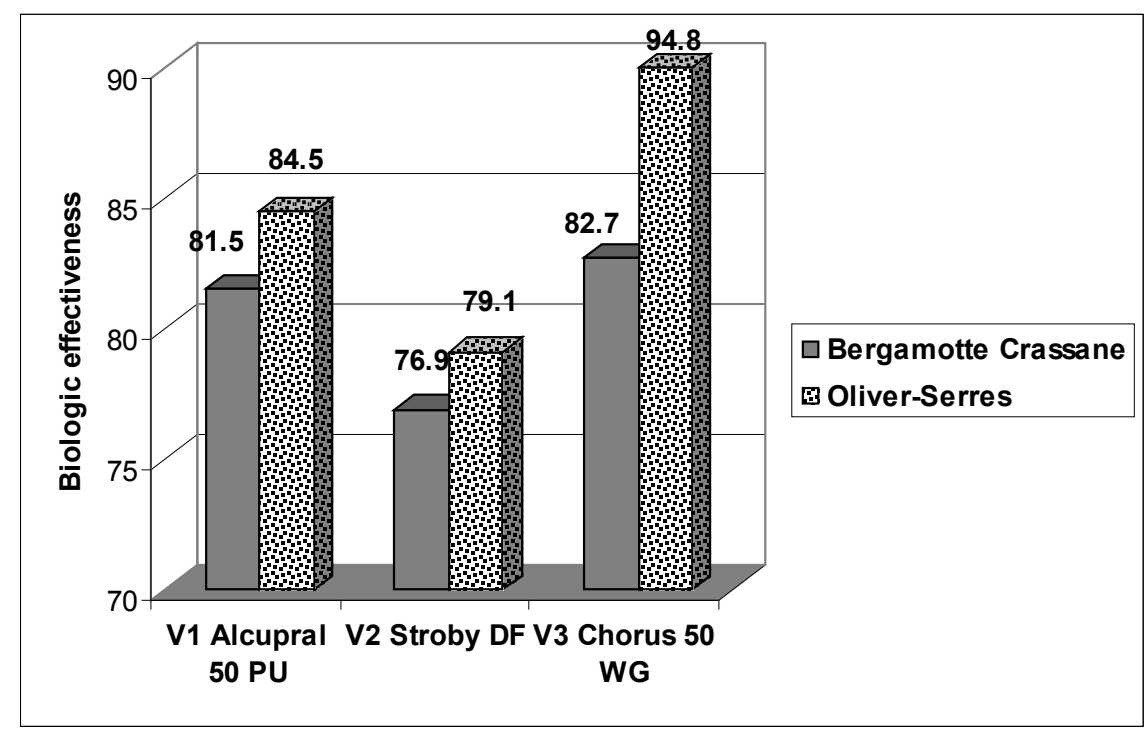

Fig. 1. The evaluation of the conservation status of habitats 
Tab. 1. Conservation status for priority species of the site.

\begin{tabular}{|c|c|c|}
\hline Type species & $\begin{array}{l}\text { Conservation } \\
\text { status }\end{array}$ & Causes that may affect the conservation status \\
\hline $\begin{array}{l}\text { Mammals } \\
\text { Canis lupus } \\
\text { Ursus arctos } \\
\text { Felis silvestris } \\
\text { Lutra lutra }\end{array}$ & favorable & $\begin{array}{c}\text { Forestry, wood transportation, hydropower development on } \\
\text { Someşul Rece River, } \\
\text { local community activities. }\end{array}$ \\
\hline $\begin{array}{l}\text { Amphibians and reptiles } \\
\text { Bombina variegata }\end{array}$ & $\begin{array}{l}\text { unfavorable- } \\
\text { inadequate }\end{array}$ & $\begin{array}{l}\text { Pressures due to the opening of forestry roads in the site, } \\
\text { modification of water regime due to hydro exploitation, the } \\
\text { construction works that require changes of the morphology } \\
\text { hydropower land, tourism activities that harm the habitat of } \\
\text { the species by improper waste disposal. }\end{array}$ \\
\hline $\begin{array}{l}\text { Fishes } \\
\text { Gobioura uranoscopus, } \\
\text { Sabanejewia aurata, Cottus } \\
\text { gobio, Eudontomyzon danfordi }\end{array}$ & favorable & $\begin{array}{l}\text { Modification of water regime due to hydro exploitation, the } \\
\text { construction works that require changes of the morphology } \\
\text { hydropower land. }\end{array}$ \\
\hline
\end{tabular}

Tab. 2. Conservation measur for habitats with unfavorable inadequate status

\begin{tabular}{|c|c|c|}
\hline $\mathrm{Nr}$. & Habitat name & Conservation measures \\
\hline 11 & $\begin{array}{l}9110 \text { - Beech forest } \\
\text { Luzulo- Fagetum }\end{array}$ & \multirow{2}{*}{$\begin{array}{c}\text { Conservative management of natural regeneration; } \\
\text { Uncontrolled logging forbided; } \\
\text { Maintenance of dead wood (fallen trees) because they provide food or } \\
\text { habitat for other species of vertebrates or invertebrates }\end{array}$} \\
\hline 22 & $\begin{array}{l}9130 \text { - Beech forest } \\
\text { Asperulo-Fagetum }\end{array}$ & \\
\hline 33 & $\begin{array}{c}9410 \text { - Acidophile } \\
\text { Picea abies }\end{array}$ & $\begin{array}{l}\text { medium and long term halting logging races. } \\
\text { halting the planting of non-indigenous species, especially conifers } \\
\text { elimination of expanding the network of forest roads }\end{array}$ \\
\hline 44 & $\begin{array}{l}\text { 91E0* - Alnus glutinosa } \\
\text { and } \\
\text { Fraxinus excelsior } \\
\text { forests }\end{array}$ & $\begin{array}{l}\text { maintaining woody plant species diversity - the role of this type of habitat } \\
\text { is for protection and ecological stability; the habitat, slows down the water, } \\
\text { protects bank erosion }\end{array}$ \\
\hline 55 & $\begin{array}{l}91 \mathrm{D} 0 * \text { - peatlands with } \\
\text { rabies forest vegetation }\end{array}$ & $\begin{array}{l}\text { prohibiting any cuts in the habitat and the adjacent habitat; } \\
\text { maintaining watercourses crossing areas; } \\
\text { avoid grazing in these areas }\end{array}$ \\
\hline
\end{tabular}

\section{8, Proorocu and Beldean, 2007).}

When the conservation status is evaluated as "unknown", the activities of the management plan should proceed to collect data in order to estabish the conservation status of the habitat type, species or group of species. The rules and the results of the human impact must reduce the effect of the present impact activities or must forbid other future activities that could affect the species or habitat type, according to the precautionary principle.

In these conditions, we must therefore avoid a situation where the species/habitat reaches an unfavorable conservation status, because of the absence or insufficient information necessary to evaluate their conservation status. Thus, measures, activities and rules of the management plan must be preventive, effective, adequate, efficient, integrated, in order to provide the framework for species and habitats of conservation interest to maintain or reach a favorable conservation status (Proorocu, 2008, Proorocu and Beldean, 2007).

When the management plan was drowed up, we have developed a series of measures for each type of habitat and for each species of the site. These measures were developed in close 
Tab. 3. Conservation measur for habits with a favorable conservation status

\begin{tabular}{ccc}
\hline Nr. & Habitat name & Conservation measures \\
\hline 11 & $7110^{*}$ - active peatlands & $\begin{array}{c}\text { moderation in operating activities peat - swamp tame } \\
\text { reduced grazing at the edges - pollution by eutrophication } \\
\text { especially in areas of marsh edge }\end{array}$ \\
\hline 22 & 6520 - Rough mountain & $\begin{array}{c}\text { - Limiting human pressures through continued practice of } \\
\text { traditional mowing and grazing a non intensive }\end{array}$ \\
\hline 33 & $\begin{array}{c}\text { 6150 -boreal grasslands and } \\
\text { Alpine silicon substrate }\end{array}$ & $\begin{array}{c}\text { - Maintaining a rational grazing; } \\
\text { - where appropriate, removing woody vegetation. }\end{array}$ \\
\hline
\end{tabular}

Tab. 4. Conservation measur for the species within the site

\begin{tabular}{|c|c|c|}
\hline No. & Habitat name & Conservation measures \\
\hline 11 & $\begin{array}{l}\text { Canis lupus } \\
\text { Ursus arctos } \\
\text { Felis silvestris } \\
\text { Lutra lutra }\end{array}$ & $\begin{array}{l}\text { prohibiting any activities in areas of steep and rocky; } \\
\text { making replanting deforested areas to the level where natural } \\
\text { regeneration is not a viable option ( } 80 \% \text { forests of different types and } \\
\text { ages, } 20 \% \text { meadows and marshes; } \\
\text { informing the population on the importance of the species (financial aid). } \\
\text { in case of small hydro, it must deliver a servitude which represent annual } \\
\text { average flow naturally minimum that is recorded in the Somesul Rece } \\
\text { River driest month of the year - for otter }\end{array}$ \\
\hline 22 & Bombina variegata & $\begin{array}{l}\text { prohibition of draining wetlands, drainage works, removing culverts, } \\
\text { preventing overflows streams on flat areas through consolidation of } \\
\text { banks, creation of artificial whites etc. } \\
\text { prohibiting the exploitation of natural resources and vegetation in } \\
\text { wetlands. } \\
\text { prohibiting the investment that modifies the hydric regime of the area or } \\
\text { requires specific interventions in natural habitats. }\end{array}$ \\
\hline 33 & $\begin{array}{c}\text { Gobioura uranoscopus, } \\
\text { Sabanejewia aurata, } \\
\text { Cottus gobio, } \\
\text { Eudontomyzon danfordi }\end{array}$ & $\begin{array}{l}\text { microhydro are not recommended because: } \\
\text { 1) induce the phenomenon of consagvinizare; } \\
\text { 2) are reduced or impaired specific habitats for breeding, feeding, resting } \\
\text { or wintering; } \\
\text { 3) natural productivity decreases. } \\
\text { removing natural or artificial barriers }\end{array}$ \\
\hline
\end{tabular}

connection with the conservation status of habitats and species, but also taking into account the needs and the opinion of local communities. These measures include: maintaining the favorable conservation status of habitats and maintain the current habitat areas. The conservation measures have been established by making field studies and bt suding and collecting bibliographic data. According to field studies, conservation status for each habitat and species was established. Knowing the state of conservation (unfavorable inadequate, favorable, unfavorable bad), we were able to develop appropriate conservation measures for all habitats and species of community interest from the site (Doniță et al., 2005; Proorocu, 2008, Proorocu and Beldean, 2007).

\section{RESULTS AND DISCUSSION}

According to field studies we could determinate that the largest land area of the site is in an unfavorable conservation status or in bad conservation status (4.600 ha).

In the following graphic, we can see the situation of the conservation status of the habitats:

Regarding fauna, mammals and fish species have a favorable conservation status, but the 
amphibian species, Bombina variegata, has an unfavorable-inadequate conservation status.

Conservation measures were elaborated for all habitats and species witin the site, ase written in the tabels below.

Conservation measures favorable to existing habitats are maintained through various activities carried out by people from the use of land.

\section{CONCLUSION}

Conservation measures ROSCI0233 Someşul Rece management plan were developed in order to protect habitats and species within the site. He measures do not prohibit local human activities within the site, being slightly more restrictive in some small and precise areas.

About the habitats we can conclude by saying that active peat habitat, with an area of 255 ha, havea favorable conservation status, along with mountain meadows ( $8.5 \mathrm{ha}$ ) and boreal and alpine meadows (8.5 ha) habitats.

Beech forests Asperulo Fagetum habitat, with an area of 85 ha, along with Alluvial forests with Alnus and Fraxinus (59 ha) habitat and peat bogs with forest habitat (426.5 ha) have an unfavorable inadequate conservation status.

Picea Abies acidophile forest habitat occupies the largest area of the site (4600 ha) and has an unfavorable bad conservation status.
Regarding the evaluation of the conservation status of species, we can conclude that mammals (wolf, bear, lynx, and otter) have a favorable conservation status. However, there are several reasons that could lead to an imbalance: forestry, wood transportation planning and related works hydropower on the river, etc.

The species of amphibian, yellow-bellied toad (Bombina variegata), has an unfavorable inadequate conservation status, due to the pressure of forestry opening roads, or modification of water regime due to hydro exploitation or the construction works that require changes of the morphology hydropower land.

All species of fish have a favorable conservation status.

For all types of habitats and species within the site, a series of conservation measures were establish, such as: stopping illegal deforestation, preserving the diversity of wood species or ensuring peace in of steep and rocky areas.

\section{REFERENCES}

1. Doniță N, Popescu A, Biriş I (2005). Habitats of Romania, Ed. Technical Forestry.

2. Proorocu M (2008). Protected Natural Areas, revised edition, Ed. Academic Press, Cluj-Napoca.

3. Proorocu M, Beldean P (2007). Natural Protected AreasPracticum, Ed. Academic Press, Cluj Napoca.

4. ***, Management plan of Natura 2000 Someșul Rece Site. On line at: http://usamvcluj.ro/ROSCI0233/.

5. ***, The Council Directive 92/43/EEC (The Habitats Directive). Official Journal of the European communities, No. I. 206/7. 